\title{
КРАВЧЕНКО О.В.
}

\author{
Вищий державний навчальний заклад України «Буковинський державний медичний \\ університет», кафедра акушерства, гінекології та перинатології, м. Чернівці
}

\section{СУЧАСНІ ПОГЛЯДИ НА ЛІКУВАННЯ НЕСПЕЦИФІЧНОГО ВУЛЬВОВАГІНІТУ ЗМІШАНОЇ ЕТІОЛОГІї}

В структурі гінекологічної захворюваності неспецифічний вульвовагініт змішаної етіології стає найбільш поширеною патологією. Полімікробні асоціації з різним ступенем етіологічної значущості компонентів, представлені як патогенними, так i, переважно, умовно-патогенними мікроорганізмами. В 78\% випадків при неспецифічному вульвовагініті висівається 2 і більше збудника, які здатні формувати полівидові біоплівки чим визначається їх висока стійкість до антибіотикотерапії.

Мета дослідження - оцінити ефективність сучасного антисептичного засобу Гінодек при лікуванні неспецифічних вульвовагінітів змішаної етіології.

Матеріал і методи дослідження. Під спостереженням було 58 пацієнток 3 верифікованим діагнозом неспецифічного вульвовагініту змішаної етіології. Критеріями виключення з дослідження були наявні специфічні інфекції (гонорея, хламідіоз тощо). Всім жінкам проводилось загально-клінічне обстеження, бактеріоскопічне та бактеріологічне дослідження, визначався рН піхвового секрету. Хворі з верифікованою вульвовагінальною інфекцією отримували препарат Гінодек - вагінальний гель 5 мл 1 раз на добу 7 днів.

Ефективність лікування оцінювали за даними клінічного обстеження до лікування та на 7 день спостереження та лабораторними (бактеріоскопічними, бактеріологічними) даними до та після лікування. Критеріями ефективності лікування була повна клінічна та бактеріальна санація: відсутність суб'єктивних клінічних симптомів, запальних змін слизової оболонки піхви, від'ємний результат мікробіологічного дослідження вагінального вмісту.

Результати дослідження та їх обговорення. Бактеріологічний аналіз мікробного спектру піхви обстежених жінок показав різне поєднання 2 і більше мікроорганізмів. Крім того у переважної більшості пацієнток (84,5\%) була різко знижена кількість лактобактерій (103 КУО/мл). Після лікування вагінальним гелем Гінодек по 5 мл 1 раз на добу протягом 7 днів, об’єктивна і суб'єктивна симптоматика запального процесу піхви повністю була купована по закінченню терапії.

Результати бактеріологічного обстеження через 2 тижня після проведеного лікування також підтвердили ефективність використання вагінального гелю Гінодек у більшості $(94,8 \%)$ жінок, при чому лактобактерії в кількості $10^{7}$ КУО/мл виявлені у 86,2\% обстежених.

Висновки. Препарат Гінодек $є$ високоефективним по відношенню до основних збудників неспецифічного вульвовагініту змішаної етіології, що робить його препаратом вибору при проведенні місцевої терапії. Гінодек не порушує функціональну активність лактобацил, забезпечує комфортний рН середовища, що сприяє швидкому відновленню нормального біотопу піхви.

Ключові слова: неспецифічний вульвовагініт змішаної етіології, лікування.

Мікробіом людини розглядається сьогодні як важливіша система, яка бере активну участь в метаболічних, регуляторних і генетичних процесах життєдіяльності організму [6, 13].

Складовою загального мікробіому жінки є вагінальний біотоп, який перебуває в тісному симбіотичному зв'язку зі структурними компонентами піхви та функціональною активністю зокрема імунної та ендокринної системи. Особливості мікробіома піхви визначаються їі анатомічною будовою, гістологічною структурою слизової оболонки, ендокринною функцією яєчників, специфікою локального кровообігу, лімфотоку і іннервації, біологічними і хімічними характеристиками піхвового секрету тощо.

Основними представниками вагінального бі- 
отопа $є$ лактобактерії. Саме вони і визначають ступінь неспецифічного захисту мікроекосистеми піхви. Для підтримки їх активної життєдіяльності необхідне кисле середовище, анаеробні умови і достатній вміст в епітелії піхви глікогену - основного субстрату метаболізму. Розпад глікогену в десквамованому епітелії в процесі забезпечення життєдіяльності лактобацил супроводжується накопиченням молочної кислоти та перекису водню, що сприяє підтримці необхідного рівня $\mathrm{pH}$ секрету піхви і створює природній фільтр на користь кислотостійких мікроорганізмів.

Захисні властивості лактобактерій реалізуються шляхом прямої антибактеріальної дії на умовно-патогенні мікроорганізми перекису водню, а також за допомогою підтримки достатньої концентрації молочної кислоти, яка забезпечує коливання pH в межах 4,0-4,5. Важливим моментом загальної системи підтримки антиінфекційного гомеостазу $є$ той факт, що лактобактерії активно конкурують 3 іншими мікроорганізмами за можливість продуктивного контакту (адгезії) з клітинами піхвового епітелію [10]. Тим самим вони стимулюють імунну систему макроорганізму, насамперед місцевий імунітет. Рівень імунної відповіді регулюється ступенем інтенсивності антигенного подразнення слизових оболонок ацидофільною мікрофлорою.

Кожна жінка має свій індивідуальний лактобацилярний набір, в якому переважають штами одного виду. Індивідуальний склад мікробіома підтримується генетичними, екологічними факторами і залежить також від режиму харчування, гігієни, використання медичних засобів, фізіологічного стану організму та віку жінки.

Дослідження останніх років показали, що в структурі гінекологічної захворюваності неспецифічний вульвовагініт змішаної етіології стає найбільш поширеною патологією. Полімікробні асоціації з різним ступенем етіологічної значущості компонентів, представлені як патогенними, так i, переважно, умовно-патогенними мікроорганізмами, які лише при певних станах (зміна $\mathrm{pH}$, зниження захисних властивостей організму, ендокринні порушення тощо) можуть викликати запальні реакції піхвового епітелію [11].

Проведені низкою науковців дослідження показали, що у жінок репродуктивного віку при неспецифічному вульвовагініті в 78\% випадків висівається 2 і більше збудників, які здатні формувати полівидові біоплівки чим визначається їх висока стійкість до антибіотикотерапії [5].

Антибіотики не можуть проникнути в середину патологічної біоплівкової структури, що робить їх малоефективними та сприяє рецидиву захворювання. Невиправдане призначення антибіотиків широкого спектру дії, безконтрольне лікування та самолікування призвело сьогодні до виникнення множинної антибактеріальної резистентності, що, в свою чергу, утруднює проведення ефективного етіотропного лікування [7].

У зв'язку з цим, постає проблема пошуку місцевих антисептичних засобів, які, з одного боку, були б високоефективними по відношенню до основних збудників запальних захворювань органів малого тазу, з другого - мінімально впливали б на стан нормального біотопу піхви, не мали би обмежень в застосуванні та не містили даних щодо формування резистентних штамів мікроорганізмів $[8$, 12]. Цим критеріям сьогодні відповідає вагінальний гель Гінодек, завдяки особливим властивостям діючих речовин у його складі $(0,02 \%$ декаметоксин, $0,5 \%$ гіалуронова кислота, лактатний буфер). Декаметоксин чинить антимікробну, протигрибкову дію, він концентрується на цитоплазматичній мембрані (ЦПМ) мікробної клітини, з'єднується 3 фосфатидними групами ліпідів оболонки, порушуючи проникність ЦПМ мікроорганізмів [4]. Декаметоксин має виражений бактерицидний вплив на стафілококи, стрептококи, капсульні бактерії та фунгіцидну дію на дріжджі, дріжджоподібні гриби тощо. Препарат високоактивний відносно мікроорганізмів, стійких до антибіотиків (пеніциліну, тетрациклінів, канаміцину, неоміцину, еритроміцину, цефалоспоринів, фторхінолонів тощо) $[1,2]$.

Гіалуронова кислота, що входить до складу Гінодека, зв'язує воду, відновлює водний баланс клітин вагінального епітелію, чим забезпечує підтримку вологості в слизовій оболонці, покращує цервіко-вагінальну трофіку і тому проявляє регенеруючі та ранозагоювальні властивості, а також усуває дискомфорт та свербіж у піхві.

Завдяки лактатному буферу гель підтримує $\mathrm{pH}$ $(3,8-4,5)$ піхвового середовища, що сприяє формуванню нормальної мікрофлори вагінального біотопу.

МЕТА ДОСЛІДЖЕННЯ - оцінити ефективність сучасного антисептичного засобу Гінодек при лікуванні неспецифічних вульвовагінітів змішаної етіології. 


\section{МАТЕРІАЛ І МЕТОДИ ДОСЛІДЖЕННЯ}

Під спостереженням було 58 пацієнток з верифікованим діагнозом неспецифічного вульвовагініту змішаної етіології. Критеріями виключення 3 дослідження були наявні специфічні інфекції (гонорея, хламідіоз тощо). Всім жінкам проводилось загально-клінічне обстеження, бактеріоскопічне та бактеріологічне дослідження, визначався $\mathrm{pH}$ піхвового секрету [3].

Хворі з верифікованою вульвовагінальною інфекцією отримували препарат Гінодек - вагінальний гель 5 мл 1 раз на добу 7 днів.

Ефективність лікування оцінювали за даними клінічного обстеження до лікування та на 7 день спостереження та лабораторними (бактеріоскопічними, бактеріологічними) даними до та після лікування. Критеріями ефективності лікування була повна клінічна та бактеріальна санація: відсутність суб'єктивних клінічних симптомів, запальних змін слизової оболонки піхви, негативний результат мікробіологічного дослідження вагінального вмісту.

\section{РЕЗУЛЬТАТИ ДОСЛІДЖЕННЯ ТА ЇХ ОБГОВОРЕННЯ}

Всі пацієнтки (58 жінок) були мешканками міста. Середній вік обстежених становив $31,3 \pm 0,2$ роки. $51(87,9 \%)$ жінка в анамнезі мала пологи. У 8 (13,8\%) обстежених були самовільні переривання вагітності. 3 (5,2\%) пацієнтки не планували вагітності на даний час і використовували гормональні контрацептивні засоби. У 4 (6,9\%) жінок встановлений діагноз первинного непліддя.

При аналізі гінекологічного анамнезу нами констатовано, що 24 (41,4\%) пацієнтки раніше лікували кольпіти різної етіології. У 20 (34,5\%) обстежених були сальпінгоофорити, 19 (32,8\%) в анамнезі мали ерозію шийки матки. У $2(3,4 \%)$ жінок був в минулому пролікований метроендометрит. 16 $(27,6 \%)$ пацієнток страждали на порушення менструального циклу.

Соматичний анамнез був обтяжений у 38 $(65,5 \%)$ обстежених: 20 (34,5\%) жінок мали захворювання шлунково-кишкового тракту, 11 (18,9\%) хворіли на хронічний пієлонефрит, у 14 (24,1\%) пацієнток була діагностована ендокринна патологія.

При клінічному дослідженні встановлено, що всі 100\% жінок скаржилися на надмірні вагінальні виділення. Відчуття дискомфорту в піхві відмічали 45 (77,6\%) пацієнток, свербіж і печіння - 39 (67,2\%), диспареунія була констатована у 22 $(37,9 \%)$ обстежених.

При об'єктивному дослідженні гіперемія піхви діагностована у $43(74,1 \%)$ жінок, незначний набряк слизової оболонки - у 13 (22,4\%). У 48 (82,7\%) пацієнток спостерігалися значні виділення зі статевих шляхів. Результати визначення $\mathrm{pH}$ піхвового середовища показали, що у всіх обстежених даний показник коливався в межах 4,5-5,0.

Після забору матеріалу на бактеріоскопічне та бактеріологічне дослідження піхва пацієнток була оброблена розчином декасану (основа декаметоксин), який має широкий спектр дії, невеликий латентний період, високу активність, є хімічно стійким, немає місцевого подразнювального або алергічного впливу на тканини. За хімічною природою декаметоксин $є$ поверхневоактивною речовиною, що зв'язує і відокремлює ліпіди від оболонок інфектантів за принципами електростатики. До отримання результатів бактеріологічного дослідження, відповідно до вимог сучасних міжнародних протоколів (протокол Міжнародної експертної ради Національного центру по контролю і профілактиці захворювань США), жінкам, в якості емпіричної локальної терапії, рекомендовано спринцювання розчином декасану [9].

При бактеріоскопічному дослідженні мазків вагінальних виділень у обстежених жінок, до лікування визначалась велика кількість лейкоцитів, змішана чи кокова флора, незначна кількість злущеного епітелію.

Діагноз неспецифічного вульвовагініту змішаної етіології був верифікований на підставі бактеріологічного дослідження. Культуральний аналіз мікробного спектру піхви показав різне поєднання $2 \mathrm{i}$ більше мікроорганізмів (стрептококу, стафілококу, кишкової палички тощо). Крім того у переважної більшості пацієнток $(84,5 \%)$ була різко знижена кількість лактобактерій - $10^{3}$ КУО/мл.

3 метою корекції вище виявлених порушень мікробіоценозу піхви, пацієнткам в подальшому призначався вагінальний гель Гінодек по 5 мл 1 раз на добу протягом 7 днів.

В процесі лікування звернуло на себе увагу дещо відмінна динаміка змін суб'єктивного стану пацієнток та результатів об'єктивного обстеження (рис. 1). 


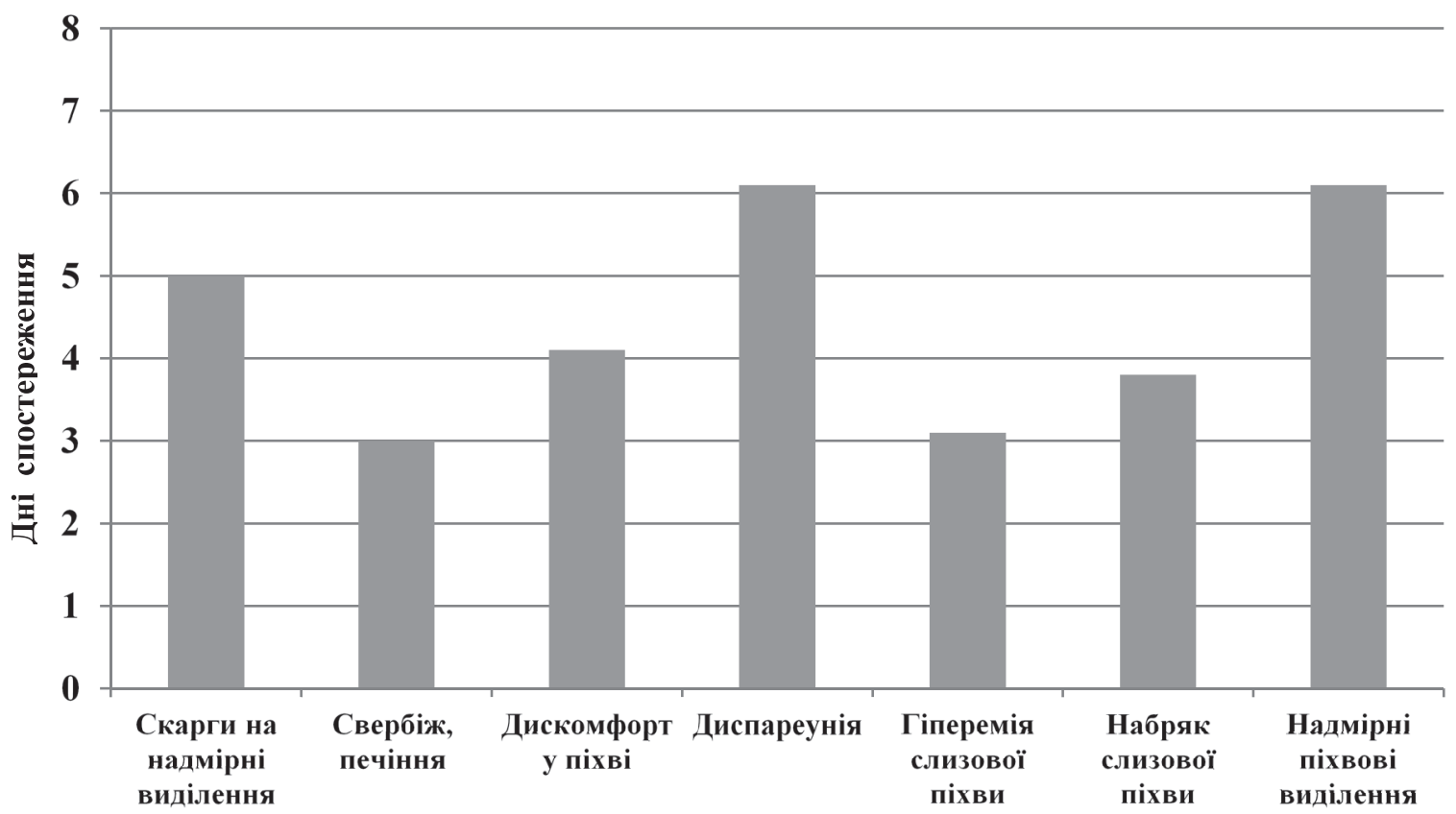

Рис. 1. Терміни купування основних клінічних проявів неспецифічного вульвовагініту змішаної етіології у обстежених паціснток

Свербіж і печіння як основний симптом був відсутній у жінок вже на 3 день лікування. Надмірні виділення не турбували пацієнток на 6 день спостереження. Після закінчення терапії скарги були відсутні у 56 (96,5\%) обстежених. Об'єктивна симптоматика запального процесу піхви також повністю була відсутня на 7 день лікування.

Результати бактеріологічного обстеження через 2 тижня після проведеної терапії також під- твердили ефективність використання вагінального гелю Гінодек у більшості (55 (94,8\%)) жінок, у 3 $(5,2 \%)$ пацієнток результат культурального дослідження показав рецидив кольпіту. Слід відзначити, що лактобактерії в кількості $10^{7} \mathrm{KУО/мл} \mathrm{були} \mathrm{у} 50$ (86,2\%) обстежених після проведеного лікування, що свідчить не тільки про купування патологічного процесу, а і про відновлення нормальної вагінальної мікрофлори (табл. 1).

Таблиця 1

Результати бактеріологічного дослідження піхвового вмісту у жінок з неспецифічним вульвовагінітом змішаної етіології в динаміці лікування

\begin{tabular}{|l|l|l|l|l|}
\hline \multirow{2}{*}{\multicolumn{1}{|c|}{ Мікроорганізм }} & \multicolumn{2}{c|}{ До лікування } & \multicolumn{2}{c|}{ Після лікування } \\
\cline { 2 - 5 } & \multicolumn{2}{|c|}{ КУО/мл } & \% паціснток & \multicolumn{2}{c|}{ КУО/мл } & \% паціснток \\
\hline Lactobacillus spp. & $10^{3}$ & 84,5 & $10^{7}$ & 86,2 \\
\hline Peptostreptococcus spp. & $10^{6}$ & 46,5 & - & - \\
\hline Corynebacterium spp. & $10^{9}$ & 36,2 & $10^{3}$ & 3,4 \\
\hline Staphylococcus spp. & $10^{7}$ & 43,1 & $10^{5}$ & 1,7 \\
\hline Streptococcus spp. & $10^{7}$ & 41,4 & $10^{5}$ & 1,7 \\
\hline Enterobacteriacea & $10^{6}$ & 31,0 & $10^{5}$ & 1,7 \\
\hline
\end{tabular}

\section{ВИСНОВКИ}

Препарат Гінодек є високоефективним по відношенню до основних збудників неспецифічного вульвовагініту змішаної етіології, що робить його препаратом вибору при проведенні місцевої терапії.
Гінодек не порушує функціональну активність лактобацил, забезпечує комфортний $\mathrm{pH}$ середовища, що сприяє швидкому відновленню нормального біотопу піхви. 


\section{ЛІТЕРАТУРА}

1. Давидова Ю.В. Профілактика інфекції ділянки хірургічного втручання у породіль групи високого ризику з коморбідністю / Ю.В. Давидова, А.О. Огородник, О.М. Наумчик // Ukrainian Journal of Perinatology and Pediatrics. - 2020. - № 2 (82). - C. 45-53. doi: 10.15574/PP.2020.82.63

2. Жіноче здоров'я: імплементація сучасних протоколів у клінічну практику: доповідь професора В.І. Пирогової на тему «Нові підходи до профілактики інфекційно-запальних ускладнень в акушерсько-гінекологічній практиці» // Медичні аспекти здоров'я жінки. - 2016. - №4 (101). - С. 54-61

3. Клинические рекомендации по диагностике и лечению заболеваний, сопровождающихся патологическими выделениями из половых путей женщин. - М.: Российское общество акушеров-гинекологов, 2019. - 56 с.

4. Клінічний досвід в оптимізації репаративних процесів шийки матки після деструктивно-хірургічних втручань / О.А. Таран, О.В. Булавенко, Д.Г. Коньков, Т.В. Лобастова // Здоровье женщины. - 2019. - №3 (139). - С. 38-42. doi: 10.15574/HW.2019.139.38

5. Кравченко О.В. Терапія вульвовагінітів у вагітних як метод профілактики розвитку перинатальних ускладнень / Кравченко О.В.// Репродуктивная эндокринология. - 2019. - № 4 (48). - C. 56-58. doi: 10.18370/2309-4117.2018.48.56-58

6. Микробиом и здоровье женщины (обзор литературы) Д.С. Янковский, В.П. Широбоков, Ю.Г. Антипкин [и др.] // Репродуктивна ендокринологія. - 2015. - №4 (24). - С. 13-28.

7. Намазова-Баранова Л.С. Антибиотикорезистентность в современном мире / Намазова-Баранова Л.С., Баранов А.А // Педиатрическая фармакология. - 2017. - №14 (5). - С. 341-354. doi: 10.15690/pf.v14i5.1782

8. Пустотина О.А. Обзор современных рекомендаций ведения женщин с выделениями из половых путей / Пустотина О.А., Остроменский В.В. // Акушерство и гинекология. - 2019. - №5. - C.180-184. doi: 10.18565/aig.2019.5.180-184

9. Эмпирическая терапия вульвовагинитов у женщин репродуктивного возраста в рутинной клинической практике / Радзинский В.Е., Ануфриева В.Г., Белинина А.А. [и др.] // Акушерство и гинекология. - 2020. - № 2. - С.160-168. doi: 10.18565/aig.2020.2.161-168

10. A review on anti-adhesion therapies of bacterial diseases / Asadi A., Razavi S., Talebi M., Gholami M. // Infection. 2019. - № 47. - P. 25-26. doi: 10.1007/s15010-018-1222-5

11. Diagnosis and microecological characteristics of aerobic vaginitis in outpatients based on preformed enzymes / Z. Wang, L. Fu, Z. Xiong, Q. Qin, T. Yu, Y. Wu [et. al.] // Taiwanese Journal of Obstetrics \& Gynecology. - 2016. - Vol. 55, Issue 1. - P. 40-44. doi: 10.1016/j.tjog.2015.06.012

12. European (IUSTI/WHO) Guideline on the management of vaginal discharge / [Sherrard J., Wilson J., Donders G., Mendling W., Jensen J.S.] // Int. J. STD AIDS. - 2018. - № 29(13). - P. 1258-1272 doi: 10.1177/0956462418785451

13. Kovachev S. Deference factors of vaginal lactobacilli / Kovachev S. // Critical Reviews in Microbiology. - 2018. - № 44 (1). - P.31-39. doi: 10.1080/1040841X.2017.1306688

\section{REFERENCES}

1. Davydova YUV, Ohorodnyk AO, Naumchyk OM. Prevention of infection of the area of surgical intervention in women of high risk with comorbidity. Ukrainian Journal of Perinatology and Pediatrics. 2020;2(82):45-53. (in Ukrainian) doi: 10.15574/PP.2020.82.63

2. Women's health: implementation of modern protocols in clinical practice: a report by Professor VI Pirogova on New approaches to the prevention of infectious and inflammatory complications in obstetric and gynecological practice. Medical aspects of women's health. 2016;4(101):54-61

3. Klinicheskiye rekomendatsii po diagnostike i lecheniyu zabolevaniy, soprovozhdayushchikhsya patologicheskimi vydeleniyami iz polovykh putey zhenshchin [Clinical guidelines for the diagnosis and treatment of diseases accompanied by pathological discharge from the genital tract of women]. Moscow:Russian Society of Obstetricians and Gynecologists; 2019.56 p. (in Russian)

4. Taran OA, Bulavenko OV, Kon'kov DH, Lobastova TV. Clinical experience in the optimization of reparative processes of the cervix after destructive surgery. Women's Health. 2019;3(139):38-42 (in Ukrainian) doi: 10.15574/ HW.2019.139.38

5. Kravchenko OV. Therapy of vulvovaginitis in pregnant women as a method of prevention of perinatal complications. Reproductive endocrinology. 2019;4(48):56-58. (in Ukrainian) doi: 10.18370/2309-4117.2018.48.56-58

6. Yankovskyi DS, Shyrobokov VP, Antypkin YG, Tatarchuk TF, Dyment HS. Microbiome and women's health (literature review). Reproductive endocrinology. 2015;4(24):13-28.

7. Namazova-Baranova LS, Baranov AA. Antibiotic resistance in the modern world. Pediatric Pharmacology. 2017;14(5):341354. (in Russian) doi: 10.15690/pf.v14i5.1782

8. Pustotina OA, Ostromensky VV. Review of modern recommendations for the management of women with discharge from the genital tract. Obstetrics and gynecology. 2019;5:180184. (in Russian) doi: 10.18565/aig.2019.5.180-184

9. Radzynskyy VE, Anufryeva VH, Belynyna AA, et. al. Empirical therapy of vulvovaginitis in women of reproductive age in routine clinical practice. Obstetrics and gynecology. 2020;2:160-168. (in Russian) doi: 10.18565/aig.2020.2.161168

10. Asadi A, Razavi S, Talebi M, Gholami M. A review on antiadhesion therapies of bacterial diseases. Infection. 2019;47:2526. doi: $10.1007 / \mathrm{s} 15010-018-1222-5$

11. Wang Z, Fu L, Xiong Z, et. al. Diagnosis and microecological characteristics of aerobic vaginitis in outpatients based on preformed enzymes. Taiwanese Journal of Obstetrics \& Gynecology. 2016;55:40-44. doi: 10.1016/j.tjog.2015.06.012

12. Sherrard J, Wilson J, Donders G, Mendling W, Jensen JS. European (IUSTI/WHO) Guideline on the management of vaginal discharge. Int. J. STD AIDS. 2018;29(13):1258-1272. doi: $10.1177 / 0956462418785451$

13. Kovachev S. Deference factors of vaginal lactobacilli. Critical Reviews in Microbiology. 2018;44(1):31-39. doi: 10.1080/1040841X.2017.1306688

\section{PE3ЮME}

\section{СОВРЕМЕННЫЕ ВЗГЛЯДЫ НА ЛЕЧЕНИЕ НЕСПЕЦИФИЧЕСКОГО ВУЛЬВОВАГИНИТА СМЕШАННОЙ ЭТИОЛОГИИ}

\section{КРАВЧЕНКО Е.В.}

В структуре гинекологической заболеваемости неспецифический вульвовагинит смешанной этиологии становится наиболее распространенной патологией. Полимикробные ассоциации с разной степенью этиологической значимости компонентов, представлены как патогенными, так и, преимущественно, условно-патогенными микроорганизмами. В 78\% случаев при неспецифическом вульвовагините высевается 2 и более возбудителя, которые способны формировать поливидовые биопленки чем определяется их высокая устойчивость к антибиотикотерапии.

Цель исследования - оценить эффективность современного антисептического средства Гинодек при лечении неспецифических вульвовагинитов смешанной этиологии.

Материал и методы исследования. Под наблюдением было 58 пациенток с верифицированным диагно- 
зом неспецифического вульвовагинита смешанной этиологии. Критериями исключения из исследования были обнаружение специфические инфекции (гонорея, хламидиоз и т.п.). Всем женщинам проводилось клиническое обследование, бактериоскопическое и бактериологическое исследование, определялся $\mathrm{pH}$ влагалищного секрета. Больные с верифицированной вульвовагинальной инфекцией получали препарат Гинодек - вагинальный гель 5 мл 1 раз в сутки 7 дней.

Эффективность лечения оценивали по данным клинического обследования до лечения и на 7 день наблюдения, а также лабораторными (бактериоскопическими, бактериологическими) данными до и после лечения. Критериями эффективности лечения была полная клиническая и бактериальная санация: отсутствие субъективных клинических симптомов, воспалительных изменений слизистой оболочки влагалища, отрицательный результат микробиологического исследования влагалищного содержимого.

Результаты исследования и их обсужсение. Бактериологический анализ микробного спектра влагалища обследованных женщин показал различное сочетание 2 и более микроорганизмов. Кроме того у подавляющего большинства пациенток $(84,5 \%)$ было резко снижено количество лактобактерий $\left(10^{3} \mathrm{KOE} / \mathrm{M}\right)$. После лечения вагинальным гелем Гинодек по 5 мл 1 раз в сутки в течение 7 дней, объективная и субъективная симптоматика воспалительного процесса влагалища полностью была купирована по окончании терапии. Результаты бактериологического обследования через 2 недели после проведенного лечения также подтвердили эффективность использования вагинального геля Гинодек у большинства $(94,8 \%)$ женщин, причем лактобактерии в количестве $10^{7} \mathrm{KOЕ/мл} \mathrm{обнаружены} \mathrm{у} 86,2 \%$ обследованных.

Bыводы. Препарат Гинодек является высокоэффективным по отношению к основным возбудителям неспецифического вульвовагинита смешанной этиологии, что делает его препаратом выбора при проведении местной терапии. Гинодек не затрагивает функциональную активность лактобацилл, обеспечивает комфортный $\mathrm{pH}$ среды, что способствует быстрому восстановлению нормального биотопа влагалища.

Ключевые слова: неспецифический вульвовагинит смешанной этиологии, лечение.

\section{SUMMARY}

\section{MODERN VIEWS ON THE TREATMENT OF NON-SPECIFIC VULVOVAGINITIS OF MIXED ETIOLOGY}

\section{KRAVCHENKO O.V.}

In the structure of gynecological morbidity, nonspecific vulvovaginitis of mixed etiology is becoming the most common pathology. Polymicrobial associations with varying degrees of etiological significance of the components are represented by both pathogenic and, mainly, opportunistic microorganisms. In $78 \%$ of cases with nonspecific vulvovaginitis, 2 or more pathogens are sown, which are capable of forming poly-species biofilms, which determines their high resistance to antibiotic therapy.

The aim of the study was to evaluate the effectiveness of the modern antiseptic agent Ginodek in the treatment of nonspecific vulvovaginitis of mixed etiology.
Material and research methods. There were 58 patients under observation with a verified diagnosis of nonspecific vulvovaginitis of mixed etiology. The exclusion criteria from the study were the detection of specific infections (gonorrhea, chlamydia, etc.). All women underwent clinical examination, bacterioscopic and bacteriological examination, and the $\mathrm{pH}$ of the vaginal secretion was determined. Patients with verified vulvovaginal infection received Ginodec - vaginal gel $5 \mathrm{ml}$ once a day for 7 days.

The effectiveness of treatment was assessed according to the data of clinical examination before treatment and on the 7th day of observation, as well as laboratory (bacterioscopic, bacteriological) data before and after treatment. The criteria for the effectiveness of treatment were complete clinical and bacterial sanitation: the absence of subjective clinical symptoms, inflammatory changes in the vaginal mucosa, and a negative result of microbiological examination of vaginal contents.

Research results and their discussion. Bacteriological analysis of the microbial spectrum of the vagina of the examined women showed a different combination of 2 or more microorganisms. In addition, the overwhelming majority of patients $(84.5 \%)$ had a sharp decrease in the number of lactobacilli (103 CFU / ml). After treatment with Gynodek vaginal gel, $5 \mathrm{ml}$ once a day for 7 days, the objective and subjective symptoms of the inflammatory process of the vagina were completely arrested at the end of therapy. The results of bacteriological examination 2 weeks after the treatment also confirmed the effectiveness of using the Ginodek vaginal gel in most (94.8\%) women, and lactobacilli in the amount of $107 \mathrm{CFU} / \mathrm{ml}$ were found in $86.2 \%$ of the examined.

Conclusions. The drug Ginodec is highly effective against the main causative agents of nonspecific vulvovaginitis of mixed etiology, which makes it the drug of choice for local therapy. Gynodek does not affect the functional activity of lactobacilli, provides a comfortable $\mathrm{pH}$ of the environment, which contributes to the rapid restoration of the normal vaginal biotope.

Key words: nonspecific vulvovaginitis of mixed etiology, treatment. 